\title{
Scoping assessment of groundwater doses to biota at the Sellafield site, UK
}

\author{
P. McDonald, P. Gleizon, I.A. Coleman, S.J. Watts, \\ J. Vives i Batlle and A.D. Smith \\ Westlakes Scientific Consulting Ltd., The Princess Royal Building, Westlakes Science \\ and Technology Park, Moor Row, CA24 3LN Cumbria, UK
}

\begin{abstract}
In investigating the impact of discharges from the nuclear industry on non-human biota, much attention has been given to biota in marine and terrestrial environments. Relatively little attention to date has been given to the exposure of biota to groundwater containing man-made radionuclides. This area of interest is growing especially in the field of nuclear waste repositories. A scoping assessment has been performed to determine the impacts due to radiological contamination on organisms living within or coming into contact with groundwater at the Sellafield site, UK. For time periods up to 2120, modelling of contaminant release from in-ground inventories and transport in groundwater was carried out using a relatively simple assessment methodology with the MONDRIAN modelling suite. Calculated equivalent dose rates to freshwater and marine biota were significantly higher at groundwater sites within the Sellafield boundary than at locations offsite. In general, the total weighted absorbed dose rates calculated in this scoping assessment were of no radiological significance in relation to the England and Wales Environment Agency freshwater ecosystem trigger level $\left(40 \mu \mathrm{Gy} \mathrm{h}^{-1}\right)$. The one exception to this was for bacteria, although the calculated exposure rate is believed to be inconsequential due to the very small size of bacteria.
\end{abstract}

\section{INTRODUCTION}

In the current climate of investigating the impact of discharges from the nuclear industry on non-human biota, much attention has been given to biota in marine and terrestrial environments in receipt of authorised discharges of liquid and gaseous effluent. Relatively little attention to date has been given to the exposure of biota to groundwater containing man-made radionuclides. This area of interest is growing especially in the field of nuclear waste repositories. A scoping assessment has been performed here to determine the impacts due to radiological contamination on organisms living within or coming into contact with groundwater at the Sellafield site, UK.

The following potential exposure routes to biota were identified:

1. Organisms living within groundwater;

2. Groundwater discharges to the surface at beach springs (i.e. emerging above the low water line);

3. Groundwater discharges to nearby surface water bodies (e.g. rivers);

4. Groundwater discharges directly to the Irish Sea.

In order to evaluate impacts on organisms living within, contacting or ingesting groundwater, it was necessary to determine the activity concentration of radionuclides in the groundwater. For time periods up to 2120, modelling of contaminant release from in-ground inventories and transport in groundwater was carried out for this scoping study using a relatively simple assessment methodology with the MONDRIAN modelling suite.

\section{GROUNDWATER MODEL}

The model represents groundwater flow through the geosphere as a network of discrete homogeneous legs, linked at nodes along pre-identified flowpaths. These network legs provide a basic physical 
framework for all calculations implemented within the MONDRIAN suite. The network model is calibrated by matching observed and simulated hydraulic heads through adjusting input fluxes and hydraulic conductivities within a pre-defined, physically based range. The network model groundwater pathways are shown in Figure 1. Two model time periods were considered: t1 from 1950 to 2006 (56 years) and t 2 from 2006 to 2120 (114 years). A timestep of 1 year was used in both cases, with model output produced at 5-year intervals in period t 1 and 10 year intervals in period t2. A total of 38 sources were considered along with the time period over which contaminant releases are believed to have occurred and the model network pathways with which they are associated. Calculated activity concentrations of radionuclides $\left(\mathrm{Bq} \mathrm{m}^{-3}\right)$ in groundwater and receiving waters (River Ehen, coastal waters) were required as input to the dose to biota model (see below). The output data from each MONDRIAN run was compiled and then applied to the dose to biota assessment model. Environmental activity concentrations per nuclide $\left(\mathrm{Bq} \mathrm{m}^{-3}\right)$ due to discharging groundwater into the River Ehen, beach and coastal water compartments were calculated directly by the BIOS module within MONDRIAN.

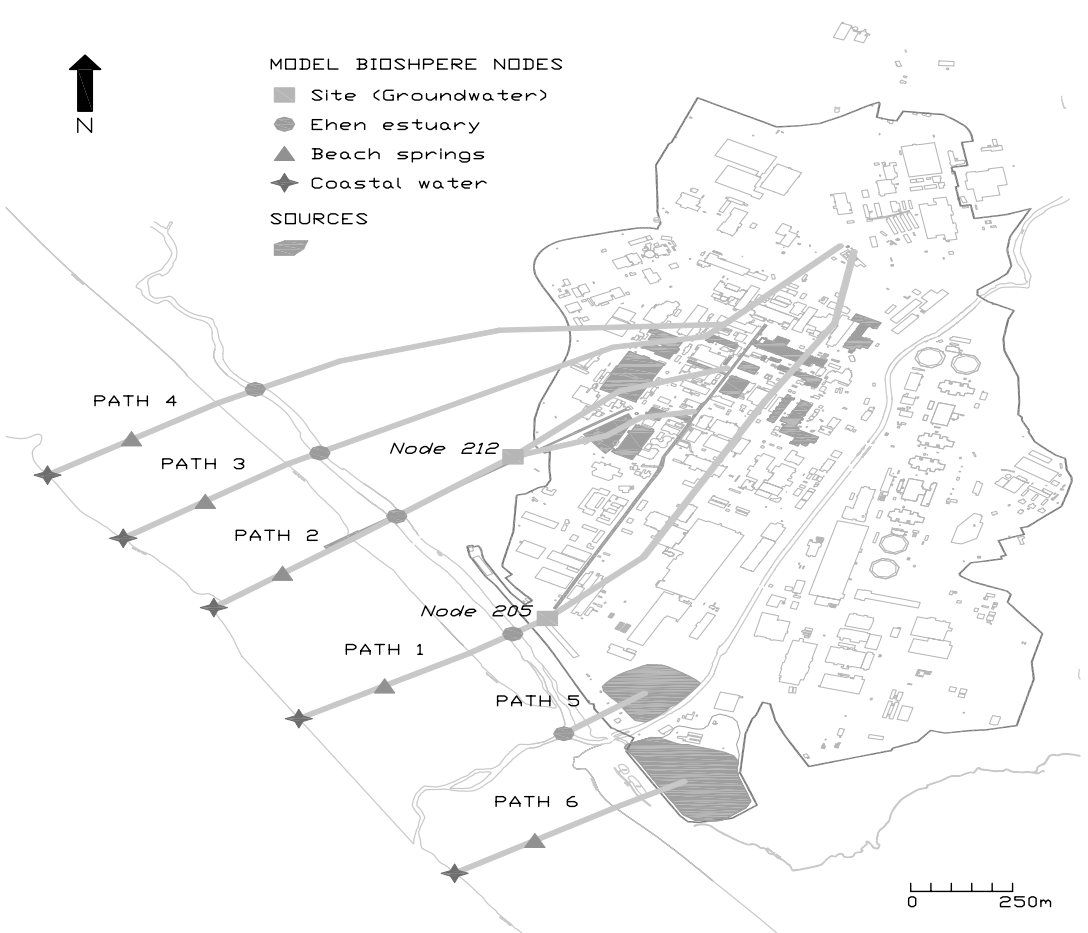

Figure 1. MONDRIAN network model groundwater pathways for Sellafield.

\section{ASSESSMENT METHODOLOGY}

The impacts of groundwater contamination to biota in rivers and the foreshore and beach were assessed using an existing methodology developed by the ERICA programme [1-3]. This methodology consisted of spreadsheets for the assessment of doses to biota in coastal aquatic and freshwater ecosystems. The set of radionuclides considered comprised of: ${ }^{3} \mathrm{H},{ }^{14} \mathrm{C},{ }^{36} \mathrm{Cl},{ }^{60} \mathrm{Co},{ }^{89,90} \mathrm{Sr},{ }^{95} \mathrm{Zr},{ }^{94,95} \mathrm{Nb},{ }^{99} \mathrm{Tc},{ }^{106} \mathrm{Ru}$, ${ }^{129,131} \mathrm{I},{ }^{134,135,137} \mathrm{Cs},{ }^{144} \mathrm{Ce},{ }^{210} \mathrm{~Pb},{ }^{210} \mathrm{Po},{ }^{226} \mathrm{Ra},{ }^{228,230,232} \mathrm{Th},{ }^{234,235,238} \mathrm{U},{ }^{237} \mathrm{~Np},{ }^{238-241} \mathrm{Pu},{ }^{241} \mathrm{Am}$ and ${ }^{242,244} \mathrm{Cm}$. For the freshwater ecosystem, the following reference organisms were covered: bacterium, phytoplankton, zooplankton, crustacean, insect larvae, vascular plant, gastropod, amphibian, bivalve, 
mollusc, pelagic fish, benthic fish, mammal and bird. For the coastal aquatic (marine) ecosystem the organisms covered were: bacterium, phytoplankton, zooplankton, benthic mollusc, benthic worm, vascular plant, pelagic fish, marine bird, macroalgae cluster, benthic fish, crustacean and mammal. Each spreadsheet used dose per unit concentration factors (CF's) for low $\beta, \beta+\gamma$ and $\alpha$ radioactivity, for the appropriate reference organisms and radionuclides, all fully compatible with ERICA-reported data. Use of CF's permitted concentrations in organisms to be automatically produced, whereupon the model calculated doses for all radionuclides. For the present assessment, default ERICA CFs were used for screening purposes.

\section{RESULTS AND DISCUSSION}

Dose assessments for all four scenarios (Groundwater sites 205 and 212; River Ehen, Sellafield Beach; Sellafield Coastal Waters) were performed. Weighted absorbed dose rates for biota inhabiting groundwater sites 205 and 212, River Ehen, beach and coastal waters are given in Tables 1-5 in units of $\mu \mathrm{Gy}^{-1}$. Each table contains data for FASSET reference organisms identified as being of interest at each particular location. It is evident from the MONDRIAN-modelled radionuclide activity concentrations (Tables 1 to 5) that the only radionuclides that had the potential to reach the foreshore or rivers within the 1951-2120 timeframe (and therefore usable in calculating exposure rates to biota) were those that are more environmentally mobile $\left({ }^{3} \mathrm{H},{ }^{14} \mathrm{C},{ }^{36} \mathrm{Cl},{ }^{60} \mathrm{Co},{ }^{90} \mathrm{Sr},{ }^{99} \mathrm{Tc},{ }^{129} \mathrm{I},{ }^{210} \mathrm{~Pb},{ }^{210} \mathrm{Po},{ }^{226} \mathrm{Ra},{ }^{230} \mathrm{Th}\right.$ and

${ }^{237} \mathrm{~Np}$ ). It is not surprising that radionuclides such as these register a signal above zero whilst less mobile radionuclides, such as the actinides, do not: the latter would take considerably greater time to migrate in groundwater through the soil/rock, given their larger $\mathrm{K}_{\mathrm{d}}$ values. Only ${ }^{3} \mathrm{H},{ }^{14} \mathrm{C},{ }^{36} \mathrm{Cl},{ }^{60} \mathrm{Co},{ }^{129} \mathrm{I}$ and ${ }^{226} \mathrm{Ra}$ groundwater concentrations have peaked in the past (in 1960-1990) as a result of them being the fastest migrating radionuclides.

\subsection{Groundwater sites 205 and 212}

Calculated weighted absorbed dose rates for the organisms of interest at the groundwater sites ranged from $0.000182-107 \mu \mathrm{Gy} \mathrm{h}^{-1}$ (Site 205) and from 0.000113-0.238 $\mu \mathrm{Gy} \mathrm{h}^{-1}$ (Site 212). For groundwater site 205 (Table 1), the highest total weighted absorbed dose rate $\left(107 \mu \mathrm{Gy} \mathrm{h}^{-1}\right)$ was predicted for bacteria in 2060. The second highest dose rate $\left(66.8 \mu \mathrm{Gy} \mathrm{h}^{-1}\right)$ was also predicted for bacteria, in 2080 . This declining trend continued with a total weighted absorbed dose rate to bacteria falling to $1.45 \mu \mathrm{Gy} \mathrm{h}^{-1}$ by 2120 . These dose rates were almost exclusively due to ${ }^{90} \mathrm{Sr}$, the concentration of which was predicted to peak at site 205 in 2060. Crustaceans were predicted to be exposed to dose rates of 38.2 and $23.9 \mu \mathrm{Gy} \mathrm{h}^{-1}$ in 2060 and 2080, respectively. Once again, these doses were predominantly due to the presence of ${ }^{90} \mathrm{Sr}$. Total weighted absorbed dose rates to insect larvae were at least an order of magnitude lower than those received by either bacteria or crustacea at site 205. The highest total weighted absorbed dose rate predicted for either bacteria, crustacea or insect larvae at groundwater site 212 occurred for crustacea (Table 1). The data showed an increase in dose rate for this organism over the period 20052120 , with a peak dose rate of $0.24 \mu \mathrm{Gy} \mathrm{h}^{-1}$ predicted at the end of the modelled period in 2120 . These dose rates were predicted to be influenced mostly by ${ }^{60} \mathrm{Co}$ (only initially), and more specifically by ${ }^{99} \mathrm{Tc}$ and ${ }^{226} \mathrm{Ra}$. Concentrations of ${ }^{99} \mathrm{Tc}$ reaching the site gradually decreased over this period, whilst ${ }^{226} \mathrm{Ra}$ concentrations steadily increased.

\subsection{River Ehen}

Total weighted absorbed dose rates for the organisms of interest in the River Ehen range between $1.32 \times 10^{-7}$ to $0.028 \mu \mathrm{Gy} \mathrm{h}^{-1}$ (Table 2). The highest total weighted absorbed doses are predicted for bacteria and the bivalve mollusc in 2060 at 0.028 and $0.020 \mu \mathrm{Gy} \mathrm{h}^{-1}$, respectively. Activity concentrations of ${ }^{99} \mathrm{Tc}$ and ${ }^{90} \mathrm{Sr}$ are anticipated to peak at this location in 2020 and 2060, respectively 
(Table 3). Similarly, maximum concentrations of ${ }^{14} \mathrm{C}$ and ${ }^{129} \mathrm{I}$ are predicted in 2080 , whilst the highest concentrations of ${ }^{210} \mathrm{~Pb},{ }^{210} \mathrm{Po},{ }^{226} \mathrm{Ra},{ }^{230} \mathrm{Th}$ and ${ }^{237} \mathrm{~Np}$ are not expected to enter the river until at least 2120. Thus, as for the organisms of interest at the groundwater sites, ${ }^{90} \mathrm{Sr}$ is predicted to be the dominant contributor to total dose rate due to groundwater mixing with the waters of the River Ehen.

Table 1. Weighted absorbed dose rates for biota from Groundwater Site 205 and 212, 2005-2120.

\begin{tabular}{|c|c|c|c|c|c|c|}
\hline & \multicolumn{3}{|c|}{ SITE 205 Weighted absorbed dose rate $\left(\mu \mathrm{Gy} \mathrm{h}^{-1}\right)$} & \multicolumn{3}{|c|}{ SITE 212 Weighted absorbed dose rate $\left(\mu \mathrm{Gy} \mathrm{h}^{-1}\right)$} \\
\hline Year & Bacteria & Crustacean & Insect larvae & Bacteria & Crustacean & Insect larvae \\
\hline 2005 & $2.72 \mathrm{E}-03$ & $1.49 \mathrm{E}-03$ & $4.35 \mathrm{E}-04$ & $1.08 \mathrm{E}-02$ & $6.37 \mathrm{E}-02$ & 5.39E-04 \\
\hline 2020 & $2.47 \mathrm{E}-03$ & $1.07 \mathrm{E}-03$ & $1.82 \mathrm{E}-04$ & $7.67 \mathrm{E}-03$ & $6.90 \mathrm{E}-02$ & $3.60 \mathrm{E}-04$ \\
\hline 2040 & $2.87 \mathrm{E}+00$ & $1.03 \mathrm{E}+00$ & $5.43 \mathrm{E}-03$ & $4.48 \mathrm{E}-03$ & $1.07 \mathrm{E}-01$ & $2.46 \mathrm{E}-04$ \\
\hline 2060 & $1.07 E+02$ & $3.82 \mathrm{E}+01$ & $1.99 \mathrm{E}-01$ & $3.57 \mathrm{E}-03$ & $1.39 \mathrm{E}-01$ & $1.81 \mathrm{E}-04$ \\
\hline 2080 & $6.68 \mathrm{E}+01$ & $2.39 \mathrm{E}+01$ & $1.25 \mathrm{E}-01$ & $3.68 \mathrm{E}-03$ & $1.73 \mathrm{E}-01$ & $1.49 \mathrm{E}-04$ \\
\hline 2100 & $2.83 \mathrm{E}+01$ & $1.01 \mathrm{E}+01$ & $5.30 \mathrm{E}-02$ & 4.04E-03 & $2.05 \mathrm{E}-01$ & $1.26 \mathrm{E}-04$ \\
\hline 2120 & $1.45 \mathrm{E}+00$ & 5.19E-01 & $2.84 \mathrm{E}-03$ & $4.52 \mathrm{E}-03$ & $2.38 \mathrm{E}-01$ & $1.13 \mathrm{E}-04$ \\
\hline
\end{tabular}

Table 2. Weighted absorbed dose rates for biota from the River Ehen, 2005-2120.

\begin{tabular}{|c|c|c|c|}
\hline & \multicolumn{3}{|c|}{ Weighted absorbed dose rate $\left(\boldsymbol{\mu G y} \mathbf{~ h}^{-\mathbf{1}}\right)$} \\
\hline Year & Bacteria & Bivalve mollusc & Pelagic fish \\
\hline 2005 & $9.14 \mathrm{E}-07$ & $2.79 \mathrm{E}-06$ & $2.21 \mathrm{E}-07$ \\
\hline 2020 & $1.01 \mathrm{E}-06$ & $2.57 \mathrm{E}-06$ & $1.32 \mathrm{E}-07$ \\
\hline 2040 & $1.15 \mathrm{E}-03$ & $8.40 \mathrm{E}-04$ & $7.11 \mathrm{E}-05$ \\
\hline 2060 & $2.80 \mathrm{E}-02$ & $2.04 \mathrm{E}-02$ & $1.73 \mathrm{E}-03$ \\
\hline 2080 & $1.76 \mathrm{E}-02$ & $1.28 \mathrm{E}-02$ & $1.08 \mathrm{E}-03$ \\
\hline 2100 & $7.18 \mathrm{E}-03$ & $5.23 \mathrm{E}-03$ & $4.44 \mathrm{E}-04$ \\
\hline 2120 & $4.38 \mathrm{E}-04$ & $3.38 \mathrm{E}-04$ & $2.76 \mathrm{E}-05$ \\
\hline
\end{tabular}

\subsection{Beach}

Total weighted absorbed dose rates for the organisms of interest inhabiting groundwater range between $4.3 \times 10^{-10}$ to $0.0012 \mu \mathrm{Gy} \mathrm{h}^{-1}$ (Table 3 ). For marine organisms potentially coming into contact with the groundwater upwelling at the beach, total weighted absorbed dose rates range between $8.0 \times 10^{-6}$ to $0.0061 \mu \mathrm{Gy} \mathrm{h}^{-1}$ (Table 4). The highest weighted absorbed dose in both cases is predicted for bacteria in 2060. Indeed, all of the organisms of interest are predicted to receive their highest doses in 2060. The most significant nuclides in terms of contributions to the total doses are ${ }^{90} \mathrm{Sr}$ and ${ }^{210} \mathrm{Po}$ which are predicted by MONDRIAN to reach their highest concentrations in 2060 at the beach.

\subsection{Coastal waters}

Total weighted absorbed dose rates for the organisms of interest in coastal waters off Sellafield range between $2.34 \times 10^{-6}$ to $6.16 \times 10^{-4} \mu \mathrm{Gy} \mathrm{h}^{-1}$ (Table 5). The highest weighted absorbed doses are predicted for bacteria and macroalgae in 2060 at $6.16 \times 10^{-4}$ and $3.29 \times 10^{-4} \mu \mathrm{Gy} \mathrm{h}^{-1}$, respectively. Once again, all of the organisms of interest are predicted to receive their highest doses in 2060. The most significant nuclide in terms of contributions to the total doses is ${ }^{90} \mathrm{Sr}$ followed by ${ }^{99} \mathrm{Tc},{ }^{226} \mathrm{Ra}$, ${ }^{230} \mathrm{Th}$ and ${ }^{14} \mathrm{C}$.

\subsection{Radiological significance of the calculated exposures}

The IAEA recommends a maximum allowable dose rate of $400 \mu \mathrm{Gy} \mathrm{h}^{-1}$ to freshwater biota as a guideline for effects at a population level but the published data from the Environment Agency provides a guideline dose rate of $20 \mu \mathrm{Gy} \mathrm{h}^{-1}$ at the individual level (Table 6). It should be noted that the latter 
Table 3. Weighted absorbed dose rates for biota in groundwater from the beach area, 2005-2120.

\begin{tabular}{|c|c|c|c|c|c|}
\hline & \multicolumn{5}{|c|}{ Weighted absorbed dose rate $\left(\boldsymbol{\mu G y} \mathbf{~ h}^{-1}\right)$} \\
\hline Year & Bacteria & Zooplankton & Crustacean & Insect larvae & Gastropod \\
\hline 2005 & $4.64 \mathrm{E}-07$ & $1.11 \mathrm{E}-05$ & $7.66 \mathrm{E}-06$ & $8.40 \mathrm{E}-10$ & $1.77 \mathrm{E}-05$ \\
\hline 2020 & $6.23 \mathrm{E}-07$ & $1.47 \mathrm{E}-05$ & $8.89 \mathrm{E}-06$ & $4.29 \mathrm{E}-10$ & $2.29 \mathrm{E}-05$ \\
\hline 2040 & $7.35 \mathrm{E}-06$ & $1.65 \mathrm{E}-05$ & $1.15 \mathrm{E}-05$ & $1.27 \mathrm{E}-08$ & $2.98 \mathrm{E}-05$ \\
\hline 2060 & $1.18 \mathrm{E}-03$ & $5.72 \mathrm{E}-05$ & $4.32 \mathrm{E}-04$ & $2.21 \mathrm{E}-06$ & $8.52 \mathrm{E}-04$ \\
\hline 2080 & $1.07 \mathrm{E}-03$ & $5.28 \mathrm{E}-05$ & $3.90 \mathrm{E}-04$ & $1.99 \mathrm{E}-06$ & $7.69 \mathrm{E}-04$ \\
\hline 2100 & $7.39 \mathrm{E}-04$ & $4.07 \mathrm{E}-05$ & $2.72 \mathrm{E}-04$ & $1.38 \mathrm{E}-06$ & $5.39 \mathrm{E}-04$ \\
\hline 2120 & $2.24 \mathrm{E}-04$ & $2.19 \mathrm{E}-05$ & $8.73 \mathrm{E}-05$ & $4.17 \mathrm{E}-07$ & $1.78 \mathrm{E}-04$ \\
\hline
\end{tabular}

Table 4. Weighted absorbed dose rates for biota in seawater from the beach area, 2005-2120.

\begin{tabular}{|l|l|c|c|}
\hline & \multicolumn{3}{|c|}{ Weighted absorbed dose rate $\left(\boldsymbol{\mu G y} \mathbf{~ h}^{-\mathbf{1}}\right)$} \\
\hline Year & Bacteria & Worm & Crustacean \\
\hline 2005 & $3.26 \mathrm{E}-03$ & $8.01 \mathrm{E}-06$ & $1.04 \mathrm{E}-05$ \\
\hline 2020 & $4.32 \mathrm{E}-03$ & $1.04 \mathrm{E}-05$ & $1.35 \mathrm{E}-05$ \\
\hline 2040 & $4.80 \mathrm{E}-03$ & $1.26 \mathrm{E}-05$ & $1.45 \mathrm{E}-05$ \\
\hline 2060 & $6.06 \mathrm{E}-03$ & $3.11 \mathrm{E}-04$ & $1.04 \mathrm{E}-04$ \\
\hline 2080 & $5.84 \mathrm{E}-03$ & $2.81 \mathrm{E}-04$ & $9.47 \mathrm{E}-05$ \\
\hline 2100 & $5.27 \mathrm{E}-03$ & $1.97 \mathrm{E}-04$ & $6.90 \mathrm{E}-05$ \\
\hline 2120 & $4.42 \mathrm{E}-03$ & $6.59 \mathrm{E}-05$ & $2.89 \mathrm{E}-05$ \\
\hline
\end{tabular}

Table 5. Weighted absorbed dose rates for biota from the coastal area, 2005-2120.

\begin{tabular}{|c|c|c|c|c|c|c|}
\hline & \multicolumn{7}{|c|}{ Weighted absorbed dose rate $\left(\boldsymbol{\mu G} \mathbf{~ h}^{-1}\right)$} \\
\hline Year & Bacteria & Mollusc & Pelagic fish & Macroalgae & Benthic fish & Crustacean \\
\hline 2005 & $3.13 \mathrm{E}-05$ & $4.39 \mathrm{E}-06$ & $2.34 \mathrm{E}-06$ & $1.13 \mathrm{E}-04$ & $2.43 \mathrm{E}-06$ & $6.52 \mathrm{E}-06$ \\
\hline 2020 & $3.15 \mathrm{E}-05$ & $6.56 \mathrm{E}-06$ & $3.04 \mathrm{E}-06$ & $1.99 \mathrm{E}-04$ & $3.10 \mathrm{E}-06$ & $1.04 \mathrm{E}-05$ \\
\hline 2040 & $4.43 \mathrm{E}-05$ & $5.81 \mathrm{E}-06$ & $3.47 \mathrm{E}-06$ & $1.06 \mathrm{E}-04$ & $3.80 \mathrm{E}-06$ & $7.56 \mathrm{E}-06$ \\
\hline 2060 & $6.16 \mathrm{E}-04$ & $5.34 \mathrm{E}-05$ & $2.76 \mathrm{E}-05$ & $3.29 \mathrm{E}-04$ & $3.99 \mathrm{E}-05$ & $4.86 \mathrm{E}-05$ \\
\hline 2080 & $4.84 \mathrm{E}-04$ & $4.11 \mathrm{E}-05$ & $2.17 \mathrm{E}-05$ & $2.40 \mathrm{E}-04$ & $3.11 \mathrm{E}-05$ & $3.73 \mathrm{E}-05$ \\
\hline 2100 & $3.04 \mathrm{E}-04$ & $2.48 \mathrm{E}-05$ & $1.36 \mathrm{E}-05$ & $1.39 \mathrm{E}-04$ & $1.90 \mathrm{E}-05$ & $2.26 \mathrm{E}-05$ \\
\hline 2120 & $1.37 \mathrm{E}-04$ & $9.48 \mathrm{E}-06$ & $5.97 \mathrm{E}-06$ & $4.65 \mathrm{E}-05$ & $7.64 \mathrm{E}-06$ & $8.86 \mathrm{E}-06$ \\
\hline
\end{tabular}

value has recently been increased for freshwater habitats assessments to $40 \mu \mathrm{Gy} \mathrm{h}^{-1}$ as the trigger level above which further investigations should be made at the population level (Copplestone, D., Environment Agency, pers. comm.).

It is clearly evident from the data in Tables 1-5 that the majority of total weighted absorbed dose rates for the organisms of interest at each location tend to be very low. The maximum dose rate criteria recommended by the IAEA appears not to be exceeded for any of the species of interest. The only instances where the newly adopted total weighted absorbed dose rates exceed the threshold level of $40 \mu \mathrm{Gy} \mathrm{h}^{-1}$ are:

- 2060: total weighted absorbed dose rate to bacteria at site 205 of $107 \mu \mathrm{Gy} \mathrm{h}^{-1}$.

- 2080: total weighted absorbed dose rate to bacteria at site 205 of $66.8 \mu \mathrm{Gy} \mathrm{h}^{-1}$.

However, at this level of dose, exposure to microorganisms is radiologically insignificant: for animals of such a small size, the dose received would not be significantly higher than the average to the surrounding medium. This is because the range of radiation in soft biological tissue is generally higher than the typical bacteria size range of $1-5 \mu \mathrm{m}^{1}$.

\footnotetext{
${ }^{1}$ The range of beta particles (or electrons) in grams $/ \mathrm{cm}^{2}$ (thickness in $\mathrm{cm}$ multiplied by the density in $\mathrm{grams} / \mathrm{cm}^{3}$ ) is approximately half the maximum energy in $\mathrm{MeV}$. This rule overestimates the range for low energies $(0.5 \mathrm{MeV})$ and low atomic numbers, and underestimates for high energies and high atomic numbers [4].
} 
Table 6. Dose rate criteria recommended by the IAEA and resultant guideline dose rates $^{1}$ recommended in Copplestone et al. (2001).

\begin{tabular}{|c|c|c|}
\hline Ecosystem & Maximum dose rate $\left(\mu G_{y} h^{-1}\right)$ & Guideline dose rate $\left(\mu \mathbf{G y ~ h} \mathbf{h}^{-1}\right)$ \\
\hline Terrestrial & 40 & 2 \\
\hline Freshwater & 400 & 20 \\
\hline Coastal marine & 400 & 20 \\
\hline
\end{tabular}

${ }^{1}$ Guideline dose rates (5\% of the IAEA dose rate) are recommended in Copplestone et al. (2001) to take into account the uncertainties in the dose assessment calculations.

\section{CONCLUSIONS}

Screening assessments of radiological impacts upon wildlife have been performed for liquid discharges to groundwater from the Sellafield Ltd reprocessing plant at Sellafield, Cumbria. Impacts have been considered for biota at sites within reach of the groundwater flow network. Most calculated total weighted absorbed doses appear to be of no radiological significance whatsoever in relation to the new Environment Agency freshwater ecosystem trigger level $\left(40 \mu \mathrm{Gy} \mathrm{h}^{-1}\right)$, thereby obviating the need to conduct further investigations. The one exception to this is for bacteria at groundwater site 205 (107 $\mu \mathrm{Gy} \mathrm{h}^{-1}$ in 2060 and $66.8 \mu \mathrm{Gy} \mathrm{h}^{-1}$ in 2080), although this is believed to be inconsequential due to the very small size of bacteria. In addition, the maximum dose rate criteria recommended by the IAEA $\left(400 \mu \mathrm{Gy} \mathrm{h}^{-1}\right.$ ) is not exceeded for any of the species of interest at any of the locations studied.

\section{Acknowledgments}

WSC would like to acknowledge the funding and support received from Sellafield Ltd in performing this investigation.

\section{References}

[1] Copplestone D., S. Bielby, S.R. Jones, D. Patton, P. Daniel and I. Gize, 2001. Environment Agency R\&D Publication 128, Bristol, UK.

[2] Copplestone, D., M. Wood, S. Bielby, S.R. Jones, J. Vives and N.A. Beresford, 2003. Environment Agency R\&D Technical Report P3-101/SP1A, Bristol, UK.

[3] Vives i Batlle, J., S.R. Jones and J.M. Gómez-Ros, J. Radiol. Prot, 24 (2004). A13-A34.

[4] Voss, J.T. Los Alamos Radiation Monitoring Notebook. Report LA-UR-00-2584, 2001. 